\title{
What Can Political Rock Do? A Discussion Based on the Example of the Tom Robinson Band 1976-1979
}

Que peut faire le rock politique? Une étude de cas: The Tom Robinson Band (1976-79)

John Mullen

\section{(2)enEdition \\ Journals}

Electronic version

URL: http://journals.openedition.org/rfcb/1406

DOI: $10.4000 /$ rfcb.1406

ISSN: 2429-4373

Publisher

CRECIB - Centre de recherche et d'études en civilisation britannique

\section{Electronic reference}

John Mullen, «What Can Political Rock Do? A Discussion Based on the Example of the Tom Robinson Band 1976-1979 », Revue Française de Civilisation Britannique [Online], XXII-3 | 2017, Online since 05 July 2017, connection on 20 April 2019. URL : http://journals.openedition.org/rfcb/1406 ; DOI :

$10.4000 /$ rfcb.1406

This text was automatically generated on 20 April 2019.

\section{cc) () $\odot$}

Revue française de civilisation britannique est mis à disposition selon les termes de la licence Creative Commons Attribution - Pas d'Utilisation Commerciale - Pas de Modification 4.0 International. 


\title{
What Can Political Rock Do? A Discussion Based on the Example of the Tom Robinson Band 1976-1979
}

\author{
Que peut faire le rock politique? Une étude de cas : The Tom Robinson Band \\ (1976-79)
}

John Mullen

\section{Introduction}

1 Left wing rock ${ }^{1}$ musicians and fans tend to believe that rock music changes the world; left wing journalists believe that the media change the world, and left-wing teachers believe it is education. So far, so human. But is it possible to analyse the political effects of rock processes and products? This article will explore this topic with reference to one rock group, the Tom Robinson Band, which came to prominence briefly in the late nineteen seventies. ${ }^{2}$ The Tom Robinson Band proposed fast-paced mainstream rock music, not in any real sense "underground" but mixed it with very clear stances, both in lyrics and in activism, on political issues such as racism, abortion rights, unemployment, and fables about revolutionary insurrections. They released two albums - Power in the Darkness and TRB Two, before disbanding to move onto other projects. In this analysis, I will be looking not only at the "message" conveyed in the repertoire, if indeed such vocabulary is appropriate, but also at the experiences proposed by the songs.

\section{Rock, politics and dissent}

2 When one thinks of politics and rock, one generally has in mind left-wing and radical politics. There are conservative rock stars, ${ }^{3}$ but they habitually avoid singing directly about politics. Is there then something naturally radical, or at least dissenting, about rock music? Claude Chastagner in his ground-breaking work La culture du rock suggests that, in 
a sense, there is. "The subversive and the transgressive is at the heart of rock's seductive power." he writes, ${ }^{4}$ and elsewhere:

Rock is subversive because of the place it leaves for the unarticulated, for the raw sound and the undocile body, because of the place it leaves for everything which dominant culture forms reject in the name of culture. ${ }^{5}$

3 He suggests, moreover, that in its declarative, textual aspects, "Rock, above all else, is the art of the slogan". ${ }^{6}$ And slogans figure large in the world of political change.

4 Yet at the same time, rock is concerned with escapism "dreaming of lives which are more intense, more dangerous and more exciting than our own", 7 and escapism is often considered as a brake on oppositional engagement with social structures or injustices. Might rock not be just one more "heart in a heartless world", an "opiate of the masses"?

5 In any case, the subversive and the transgressive, though perhaps necessary to the building of a radical political way of life, are not in themselves political. The rock classic "Rock around the Clock", for example, celebrates the refusal to respect the rules of adult society about reasonable and respectable times to go to bed. The attitude is a hedonism which shakes up the certainties of the older generation - certainly a necessary, but insufficient, ingredient for radical politics.

6 Street, following other scholars 9 suggests that popular song, in particular folk song, can be a form of reporting of social experience. Reporting to wide audiences, a pooling of experience and of representations, a taking seriously of the living conditions of dominated sections of the population, may well be a precondition of mass political action. This "reporting" description does seem to correspond partially to some of Tom Robinson's work. Here is an extract from the song "Up against the wall":

High wire fencing on the playground

High rise housing all around

High rise prices on the high street

High time to pull it all down

white boys kicking in a window

Straight girls watching where they gone

Never trust a copper in a crime car

Just whose side are you on? ${ }^{10}$

Is "reporting" a useful description of the function of such a song? One would have to add two comments: the first is to note the emphasis on the melodramatic, which is central to much "social" content in rock music, cinema, street art or other forms of popular culture. The second, more important, is that concentrating on the idea of "reporting" and even the idea of a "message" is to underestimate the multifaceted and repetitive experience involved. The rock song is typically listened to repeatedly, quite unlike any other form of reporting, and the involvement of the listener as "co-singer" ${ }^{11}$, singing along at the concert, in the shower, or silently in their head, is a key element. The repeated nature of the experience means that transmitting information is unlikely to be the main effect of a political song. Indeed, popular song involves a particularly powerful way of sharing viewpoints and feelings and absorbing the listener. ${ }^{12}$ The listener/co-singer is putting themselves in the position of both the narrator and the rock star, using that most emotional and flexible of voices, the singing voice, as well as often mobilizing their body by dancing, tapping feet or fingers etc. "Reporting" suggests a far less immersive relationship with the content of the song than is the case for much rock. 
This immersiveness can be a political resource, placing the listener/co-singer inside the message. And rock disposes of other political resources too: it is frequently a matter of the young performing for the young, and social revolt is often more explosive among younger generations, on whom responsibilities and previous defeat weigh less heavily. Further, Rock has street legitimacy (or subcultural capital). It speaks from outside the establishments. It is not generally learned in school or sanctioned by a certificate from the conservatory: this makes it suitable for expressions of popular rebellion.

\section{Ways of being radical with popular music}

Previous writings on the use of political popular music have explored some of the ways in which producers of music have dealt with politics. One option was to (attempt to) avoid "the commercial" in the way that part of the folk revival did in the UK in the 1960s. ${ }^{13}$ The revival based itself around local folk clubs, and eschewed virtuosity and stardom for "community-based" values. Some folk clubs even insisted that singers perform only songs which came from their own home region, in a particularly sharp version of authenticitytalk. Some "underground" kinds of rock similarly aim at avoiding commercialism, critiquing big record labels and huge concert venues, hoping in this way to authentically belong to dominated groups. The music might, in these cases, then, be said to be building a counter-culture.

The exact contrary option has been to instrumentalize the commercial as much as possible. Initiatives such as Band Aid, USA for Africa, or Sun City ${ }^{14}$ insisted that raising money and/or awareness quickly was the key to political effectiveness. In the production of certain songs, there might be twenty stars only singing one line each, ${ }^{15}$ bringing to bear not so much their artistry or their political insights as their fan base. ${ }^{16}$ In this mode, the rockers are active as stars, and stars can express their solidarity with different political causes or campaigns, or play free for benefit concerts in order to raise money. The question in these cases is what can political rockers do, not in their production, but in their declarations. This is attractive to many musicians, since political activity does not follow the same rhythm as songwriting. The outbreak of a war, a scandal or a tragedy can lead to a mass political campaign of protest but songs are not generally written to order; nor can songs about "causes" easily fit every musical genre. Because of this, it can be much easier to play free in a concert, or sing on a Band Aid type single than to write a song about the cause.

11 Finally, there are ways of dealing with politics through rock which appear to be intermediate between the two modes already mentioned. This model aims to benefit from the mainstream popularity for the music at the same time as encouraging grassroots mobilization for the cause. This has sometimes been called the "Rock against Racism" model, after a 1970s initiative which organized hundreds of local concerts and a few major festivals with the aim of denouncing racism. ${ }^{17}$ Stardom is not put at the centre of the campaign as it was for Band Aid, and the political commitment asked for from fans is not just a question of contributing money. Local mobilization and smaller venues are prioritized..$^{18}$ 


\section{The approach of the Tom Robinson Band}

\section{Career and political activity}

12 The Tom Robinson Band has its particular place in this continuum, and may be considered close to the Rock against Racism approach (a campaign in which they played a part). Their priority was certainly not rejecting commercialism - the music was accessible and aimed in part at the pop charts. By way of introduction, here is what the London Evening News said about Robinson in December 1977:

Music with a hard-core political bias could soon become a regular feature of the top ten if a singer called Tom Robinson continues his sudden and mercurial rise to the top. From his position of chart success, it looks as if Robinson is prepared to launch material that combines catchy rock with lyrics that deal, as he puts it, with oppressed minorities. His current political preoccupations were brought on because, he frankly admits, he is homosexual. ${ }^{19}$

The band had begun by getting good reviews for their live concerts on the London club circuit. They did not hesitate to sign up for EMI, showing that rejecting mainstream gatekeepers was not part of their radicalism, and they soon found themselves on the front page of the New Musical Express.

Their debut album, Power in the Darkness, reached number 4 in the UK album charts and won the band a gold record, and TRB were voted "Best New Band" and "Best London Band" for the year 1977 by listeners at the Capital Radio Music Awards. "2-4-6-8 Motorway" was their first single, also released in late 1977. It reached the top five in the UK singles charts and stayed there for over a month. ${ }^{20}$

The band treated their concerts as an opportunity for encouraging political activity: punk-style fanzine bulletins would be distributed to their young audience including lyrics and interviews, but also information and phone numbers for such organizations as Gay Switchboard (which offered advice and support to closet or isolated homosexuals), the National Abortion Campaign or the National Union of School Students. They became very much involved in the Rock against Racism movement: the sleeve notes of Power in the Darkness included the founding declaration of this organization, and TRB played at the Rock against Racism festival in Spring 1978. The 1979 album TRB TWO was dedicated to Mrs. Mary Towers, the mother of Liddle Towers, an amateur boxer who had died in police custody the previous year - his case was the subject of the song "Blue Murder". 


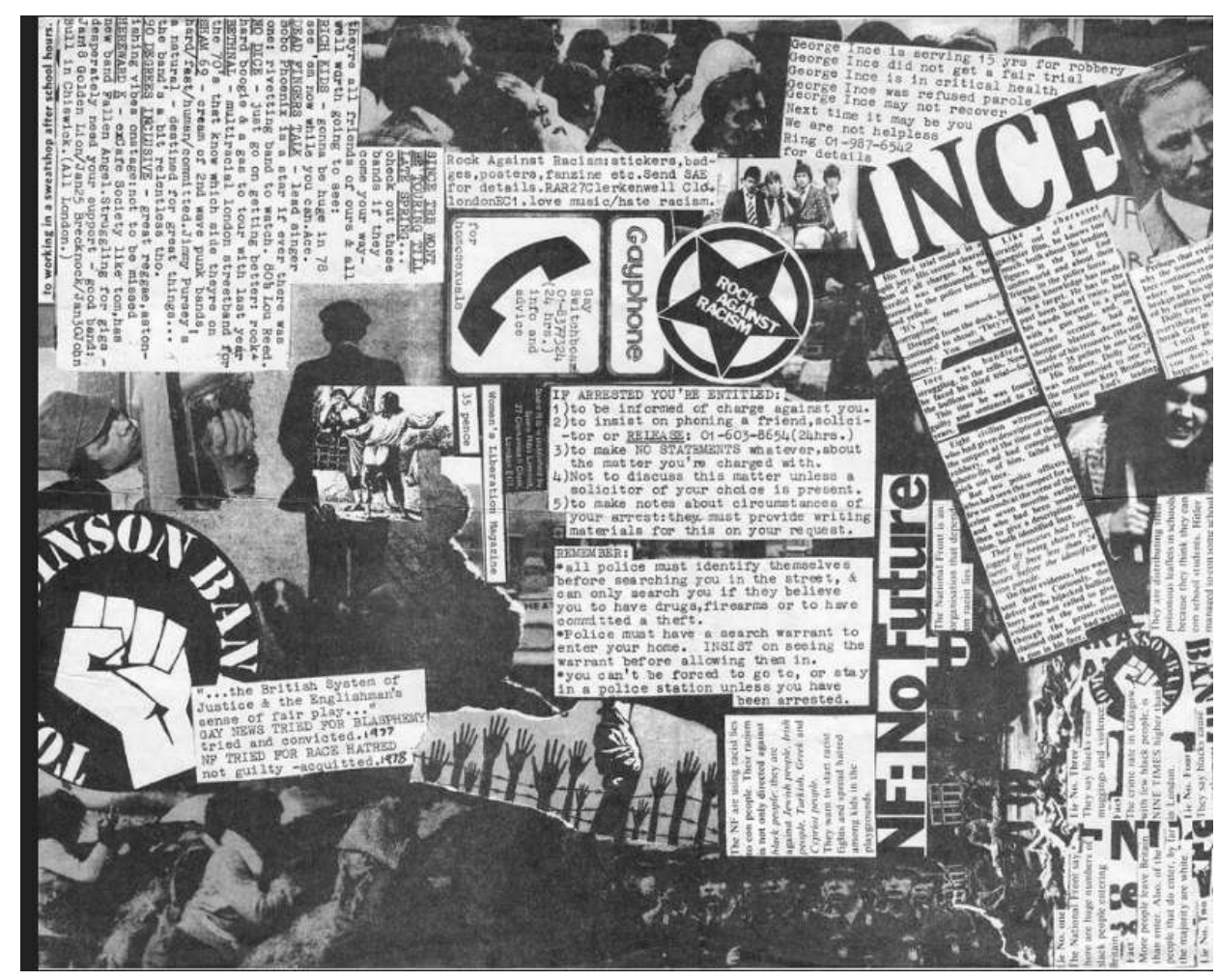

FIgURE ONE: ONE PAgE OF TRB BULLETIN N ${ }^{\circ}$, JANUARY 1978

\section{Repertoire choices}

Envisaging themselves as a political rock band, Robinson and friends set about creating a repertoire of songs. The repertoire was fashioned by the expectations of the rock and punk rock milieu and markets of the 1970s. In accordance with pre-punk genre rules, a certain level of virtuosity is displayed, yet in accordance with punk forms, the principal subjects are high points of social explosion, conflict with the elites and so on. In accordance with the rules of both genres, the repertoire is made up of original songs, almost all written by the singer himself. There is no attempt, for example, to reinterpret traditional songs of the working-class movement such as the Red Flag or the Internationale, or civil rights era anthems, Irish Republican songs etc. ${ }^{21}$ TRB's work, as rock, was very much concerned with the "shock of the new".

Denisoff, in his study of protest songs over the whole of the period 1910-64 noted a sharp decline in what he called "magnetic" protest songs, often expressed in first person plural and representing the movement ("We Shall Overcome" and such like), and a rise in what he refers to as "rhetorical" protest songs, which stress individual indignation and positioning, but do not refer to the movement directly. ${ }^{22}$ Tom Robinson's songs would certainly correspond, on the whole, to this change.

18 Taking into account these genre constraints, writing political songs which people will want to hear and sing over and over is a complex task. The present author, also a political activist, can vouch that "Don't put too much text on a leaflet" and "Don't forget to organize childcare for conferences if you want a good mix of people" are both very important messages for a progressive political movement, but neither seems promising material for a rock song. 
The pop or rock song has sometimes been described as a "three-minute novel" 23 and indeed, about half the TRB songs tell a story, about alienation, injustice, state cruelty, or insurrection; the other half are a mix of two types of songs: the general call to arms:

Power in the darkness

Frightening lies from the other side

Power in the Darkness

Stand up and fight for your rights!

And fast moving poetic collages of images:

Dark-haired dangerous schoolkids

Vicious, suspicious sixteen

Jet-black blazers at the bus stop

Sullen, unhealthy and mean

\section{Narrators}

Both in the case of the story songs and the "call to arms" songs, the choice of narrator seems to me to be central, in the context which I referred to above, where singing along should be assumed to be an important part of the experience proposed. The narrator is the person who the listener/co-singer is asked to pretend to be for a short time. The song is a sort of participatory theatre ("We're now all going to imagine we are a young man being chased by the police" etc.). In the case of a favourite song for a particular listener (often a favourite narrator, in fact), the experience will be repeated frequently over years or decades.

21 One of Tom Robinson's chosen narrators is the defeated revolutionary. He may be fleeing repression, such as in the piece "Man you never saw":

Church police were round this morning

And the army's on our track

Took away my books and papers

Only just got out the back

Just called in to tell you

That your place is being watched

Don't go into work tomorrow

Try and make it down the docks

[...] Try to make like I'm a stranger

I'm a man you never saw.

Or he may be looking back nostalgically at past struggles, as in "Winter of 79".

All you kids that just sit and whine

You should have been there back in ' 79

You say we're giving you a real hard time

You boys are really breaking my heart

[...] It was us poor bastards took the chop

When the tubes gone up and the buses stopped

Top folk still come out on top

The government never resigned

The music of "Man You Never Saw"24 follows the punk convention of singing at speed from the very first note, and presents an exciting dangerous, dynamic urgent tone suited to imagining one is a fleeing revolutionary. That of "Winter of 79" 25 is much slower, with a long instrumental lead-in, suited to the nostalgic bitter-sweet tone. Both songs have lyrics in subaltern sociolect "Man you never saw" where standard English has "man you have never seen"; "the tubes gone up" where standard English has "the tubes went up" 
etc.) to show that our narrator is a working-class activist. The listener/co-singer experiences the pleasure of briefly speaking/singing the role of these people. ${ }^{26}$

How might we interpret the choice of the defeated revolutionary as narrator? This choice allows listeners and co-singers to (pretend to) feel the pride of having fought for what is right, and the excitement of the highest points of political struggle (leafletting railway stations is a theme which would not so easily fit the rock aesthetic). Yet the story of a defeated revolutionary keeps us distant from real and controversial choices in the present, and this may make it more suitable for entertainment purposes. A song which attempts to explain the political tasks for the anticapitalist of today would be more problematic, among other things because questions of strategy and tactics are highly contentious, whereas a temporary consensus may be necessary to enjoy and sing along with a rock song.

In other songs, the stories are told by narrators who are subaltern but not activists, such as the one in "My Brother Martin", a working-class youth who spent some time in juvenile prison for attacking a policeman, an experience which is recounted with some pleasure (and the lines are cheered in concert halls).

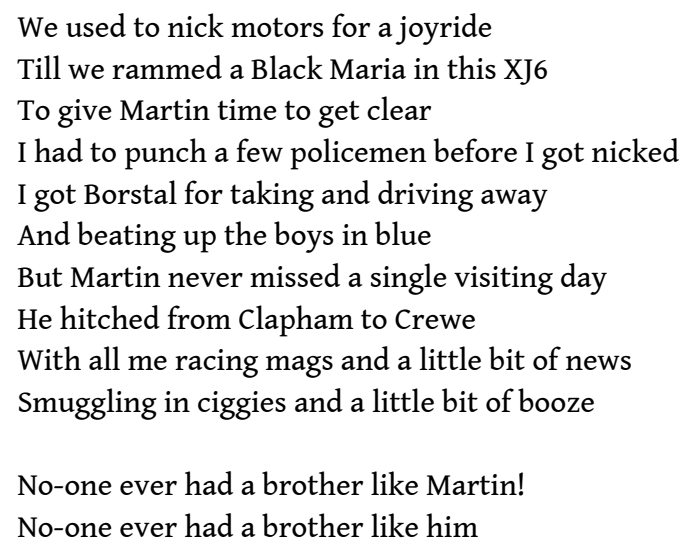

Again, then, the audience are invited to be this person and express his values. I have described this as "participatory theatre". It can also be linked to the concept of "referee design" in discourse analysis, where both speaker and listener are referred to as someone they are not (for example the ageing radio DJ who talks to his ageing audience as if we were all young). ${ }^{27}$ For the song "My brother Martin", we are all being a loveable delinquent subaltern, ${ }^{28}$ whereas in the "call to arms" songs, the narrator seems to be closer to the singer himself.

\section{"Glad to be gay" a special case in a time when visibility was the key question. ${ }^{29}$}

The song "Sing if You're Glad to be Gay" appears to me to be something of a special case. The singalong chorus involves a gay narrator refusing the most common views of the experience of homosexuality at the time. Rather than seeing himself as sinful, sick or tragic, he is announcing his sexuality in relaxedly positive terms. In this the song resembles in some ways the song "Say it loud: I'm Black and I'm Proud" by James Brown..$^{30}$ Both songs allow the listener/co-singer to take on the role of the proud member of an oppressed group, whether or not they are in fact a member or not. "Sing if you're Glad to be gay" is, however, very specific in its effect in that the social invisibility of gay people is 
a key element of the oppression. Asking a mostly non-gay audience to sing along with this refrain is proposing that they imagine themselves into the shoes of what was in the 1970s still a reviled minority; it is thus at the time a demanding song.

The success of the piece was quite astonishing, and contradicts many stereotypes of working class consensus about gays in the 1970s. When TRB played in HM Prison Chelmsford, their (literally) captive audience sang along too, before insisting that the players stay around for a chat. The music journalist present reported on Robinson:

He's gay and proud without a trace of a hurt, wounded look, and honestly now who else could get away with singing the band's theme tune/mill stone "Glad to Be Gay" to a crowd of hardened East-end street-wise prisoners? ${ }^{31}$

In 2011, the magazine Time Out listed "100 songs and other pieces of music which changed history": they included "Glad to be Gay" in illustrious company, such as that of Stravinsky's Rite of Spring. Although it is in the nature of such lists to indulge in hyperbole, it seems difficult to deny a significant political effect of this gay anthem. Its effect was heightened further by the political context: on its release, BBC Radio One refused to play it, though it was very successful on private local radios such as Capital Radio.

\section{Messages and values}

What are the messages of TRB's political rock? As I have shown above, they come from much more than the information contained in the lyrics, even though TRB's political lyrics are much more precise and less allusive than those of many other rock groups, since they seek consensus among a more tightly-defined audience than the mega-popular groups do.

The first message is a reaffirmation of the right (or even the duty) to intervene in politics, and the band positions itself against individualistic hedonism. This seemed to be much appreciated by fans of TRB, as the band was often praised as being "more political" than other bands, or "the most political" of bands. This praise I interpret as an appreciation of a clear and unapologetic declaration of the moral value of political activism. This aspect might have the effect of improving morale both among political activists or simply among people with oppositional ideas. In songs such as "Black, White, Together Tonight" and "Black Angel", radical antiracist opinions are valorized in specific stories or calls to arms, rather than simply presented.

The second kind of message is the affirmation of the value of subaltern experience. Telling stories of ordinary people's lives, of subaltern people's lives, whether the characters are workers, gays, or other oppressed groups, is a way of giving value to these people and thus standing against oppression, and also standing up against the relative absence of subaltern experience in much cultural production - mainstream television and cinema, for example. Using working class language can have the same effect. Just as the use in Britain of Jamaican dialect in reggae songs is a way of reaffirming its value against establishment dismissal, so working-class language plays a similar role in rock. "Blue Murder", about the death in police custody of Liddle Towers, is one example.

He said he screamed blue murder in the cell that night

But he must've been wrong because they all deny it. 
Gateshead station police enquired.

Liddley died.

\section{The limits}

Limits on political effectiveness for radical left artistes in the rock world are plentiful. Rock tends to work on a star system which can be contradictory with grassroots political mobilization. The symbol used by TRB, on their album covers and elsewhere (see figure two), illustrates this perfectly. The stylized fist is a well-known symbol drawn from 1970s revolutionary movements in the USA ${ }^{32}$ yet the name of the band follows the 1960s rock tradition of including the name of the star, so necessarily suggesting an overwhelming influence of one important individual - not a grassroots conception of politics. Further, the lifestyle of the somewhat successful rock group - international touring in particular ${ }^{33}$ - is hardly conducive to involvement in grassroots political activity.

Marketing codes and gatekeepers can also move production away from radical values. It is not an accident that the most popular single of the band, "2 468 Motorway", which wa very actively marketed and reached number five in the pop charts, was one of the few tracks which did not mention politics. In media interviews, moreover, Robinson was constantly under pressure to say that the music was more important than the politics.

Finally, to paraphrase Karl Marx, artistes make music, but they do not make it in circumstances of their own choosing. Tom Robinson's anti-racist anthems such as "Black, White, Together Tonight" tended to be sung, at his own concerts, by practically all-white audiences, since the expression of antiracist sentiments did not have the weight to counteract heavy socialization to segregation in 1970s popular leisure. Reggae audiences were for a long time overwhelmingly Black, punk or new wave audiences overwhelmingly White. This situation was later somewhat modified by the political voluntarism of the organization Rock against Racism who deliberately placed punk and reggae artistes on the same event, with the reggae act always as top of the bill. 


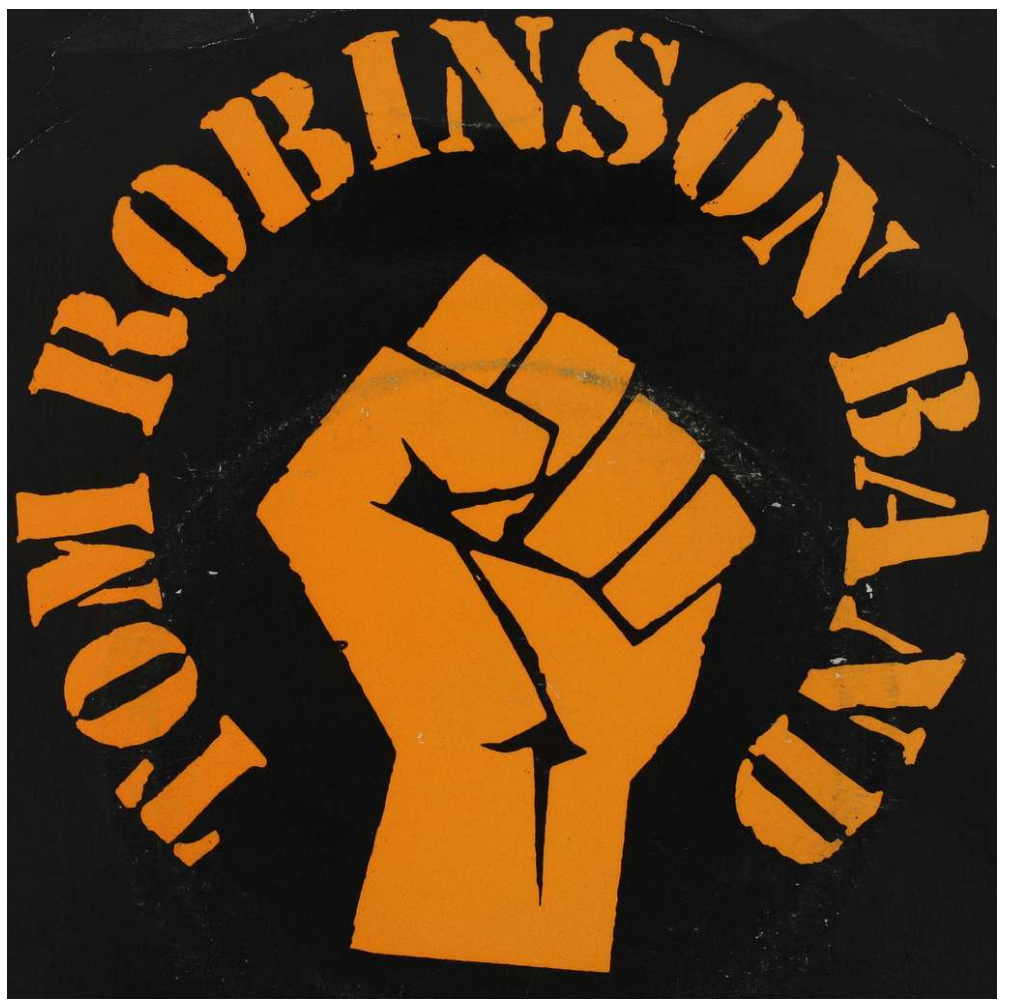

Figure two: the TRB logo

\section{Conclusion}

This article has tried to look in some detail at one example of political rock in its rhetorical, social and market context. A single group with a relatively small number of songs was deliberately chosen. Although more detailed textual and musical analysis of this work would be useful, my approach has underlined the particular importance of the participatory roles of the audiences, and the reinforcement of subaltern and radical values in a contradictory world.

Appendix 1: promotional photograph of the band 


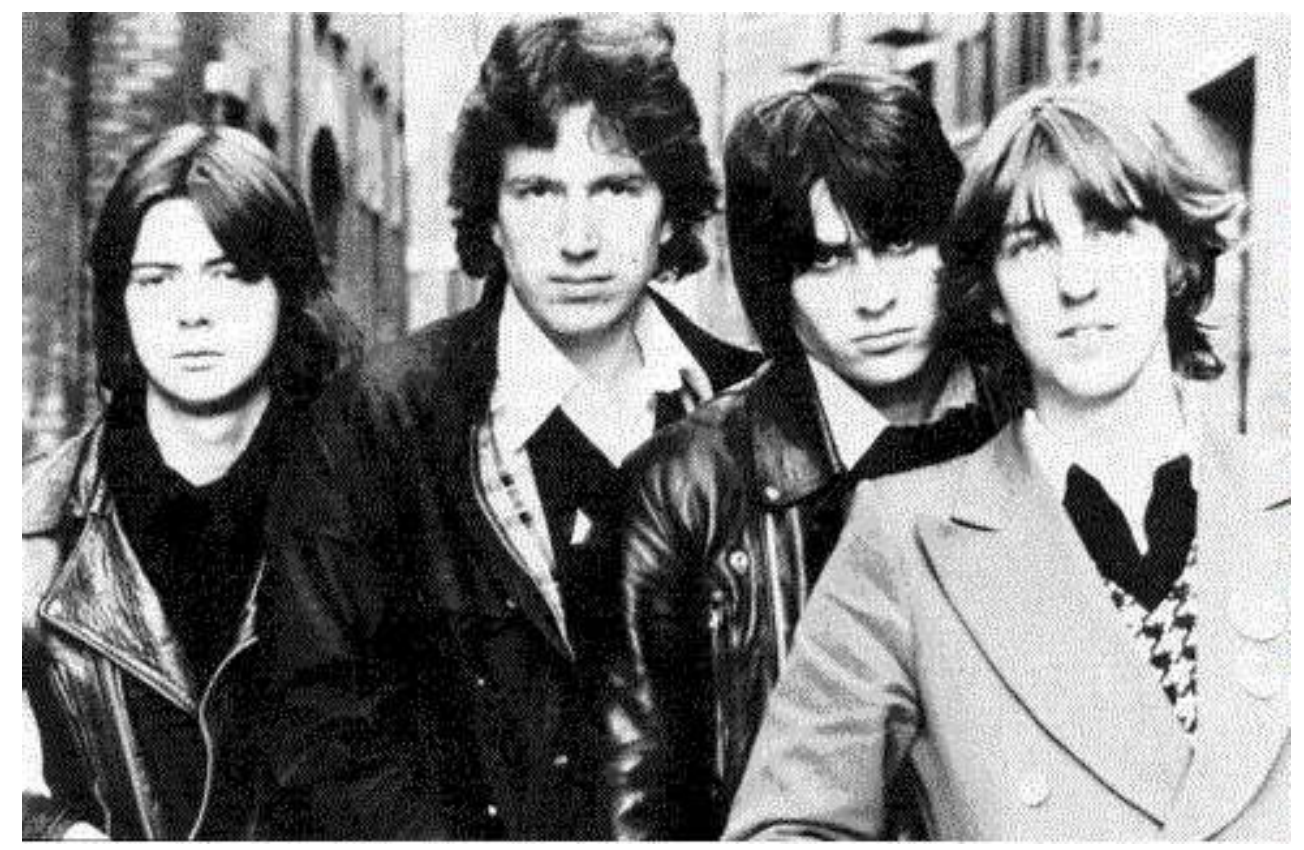

Appendix 2: songs recorded by the Tom Robinson Band

\begin{tabular}{|c|c|c|}
\hline & Theme & Information or extract of lyrics \\
\hline \multicolumn{3}{|l|}{ Single } \\
\hline 2468 Motorway & $\begin{array}{l}\text { Driving } \\
\text { through the } \\
\text { night }\end{array}$ & \\
\hline \multicolumn{2}{|l|}{ Live E P “Rising Free” 1977} & \\
\hline $\begin{array}{l}\text { Don't Take No for an } \\
\text { Answer }\end{array}$ & $\begin{array}{l}\text { Relationship song } \\
\text { apparently about } \\
\text { tensions in a couple }\end{array}$ & $\begin{array}{l}\text { "We first met in the winter } \\
\text { Said 'let's give it a try' } \\
\text { I swallowed my fears } \\
\text { A couple of years } \\
\text { Just living a lie" }\end{array}$ \\
\hline Martin & $\begin{array}{l}\text { Tribute song by } \\
\text { working class narrator } \\
\text { on the wrong side of } \\
\text { the law to his loyal } \\
\text { brother. }\end{array}$ & $\begin{array}{l}\text { "I got Borstal for taking and driving away/ } \\
\text { And beating up the boys in blue/ But } \\
\text { Martin never missed a single visiting day/ } \\
\text { He hitched from Clapham to Crewe" }\end{array}$ \\
\hline Right on, Sister & $\begin{array}{l}\text { Solidarity song to a } \\
\text { feminist activist. }\end{array}$ & $\begin{array}{l}\text { "She's a right on sister/ and she knows } \\
\text { what she likes/ she needs you and me, } \\
\text { man/ like a fish needs a bike." }\end{array}$ \\
\hline $\begin{array}{l}\text { Sing if you're glad to be } \\
\text { gay }\end{array}$ & $\begin{array}{l}\text { Ironic protest against } \\
\text { gay oppression, with } \\
\text { joyful rejoinder in } \\
\text { singalong chorus. }\end{array}$ & $\begin{array}{l}\text { "The British police are the best in the } \\
\text { world/ I don't believe none of these stories } \\
\text { I've heard..." }\end{array}$ \\
\hline
\end{tabular}




\begin{tabular}{|c|c|c|}
\hline \multicolumn{2}{|c|}{ Album : Power in the Darkness 1978} & \multirow{2}{*}{$\begin{array}{l}\text { Got to number } 4 \text { in the UK album charts } \\
\text { Consternation in Brixton/ Rioting in } \\
\text { Notting Hill Gate/ Fascists marching on } \\
\text { the high street/ Carving up the welfare } \\
\text { state/ Operator get me the hotline/ Father } \\
\text { can you hear me at all?/Telephone kiosk } \\
\text { out of order/ Spraycan writing on the wall }\end{array}$} \\
\hline $\begin{array}{l}1 \text { Up Against the Wall } \\
-\quad \text { (Robinson, Roy } \\
\text { Butterfield) }\end{array}$ & $\begin{array}{l}\text { Fantasy on insurrectionary } \\
\text { situation }\end{array}$ & \\
\hline 2 Grey Cortina & $\begin{array}{l}\text { Ironic song about being } \\
\text { jealous of a bourgeois }\end{array}$ & $\begin{array}{l}\text { "Wish I had a grey Cortina/ Whiplash } \\
\text { aerial, racing trim/ Cortina owner - no one } \\
\text { meaner/ Wish that I could be like him" }\end{array}$ \\
\hline $\begin{array}{l}3 \text { Too Good to Be } \\
\text { True - (Robinson, } \\
\text { Dolphin Taylor) }\end{array}$ & $\begin{array}{l}\text { Blues of being unemployed } \\
\text { in urban Britain }\end{array}$ & $\begin{array}{l}\text { "I've given up reading the papers/I've } \\
\text { given up watching TV/ I hope in hell I'm } \\
\text { able to tell whatever's happened to me" }\end{array}$ \\
\hline $\begin{array}{l}4 \text { Ain't Gonna Take It } \\
\text { (Robinson, Danny } \\
\text { Kustow) }\end{array}$ & $\begin{array}{l}\text { Call to arms, in particular } \\
\text { against sexism and racism }\end{array}$ & $\begin{array}{l}\text { "Women with children always carry the } \\
\text { can, till they lose them in divorce courts to } \\
\text { some pig of a man." }\end{array}$ \\
\hline 5 Long Hot Summer & $\begin{array}{l}\text { Call to arms and prediction } \\
\text { of imminent } \\
\text { insurrectionary situation }\end{array}$ & $\begin{array}{l}\text { "We can all make a stand the next time the } \\
\text { whistle blows" }\end{array}$ \\
\hline $\begin{array}{l}6 \text { The Winter of '79 } \\
\text { (Robinson, Mark } \\
\text { Ambler, } \\
\text { Kustow) }\end{array}$ & $\begin{array}{lr}\text { Many years after, ex } \\
\text { militant waxes nostalgic } \\
\text { about } & \text { failed } \\
\text { insurrectionary situation } \\
\text { leading to an - undoubtedly } \\
\text { fascist - coup d'Etat }\end{array}$ & $\begin{array}{l}\text { The Carib Club got petrol bombed/ The } \\
\text { National Front was getting awful strong/ } \\
\text { they done in Dave and Dagenham Ron/ In } \\
\text { the winter of ' } 79 \\
\text { When all the gay geezers got put inside/ } \\
\text { And coloured kids was getting crucified/ A } \\
\text { few fought back and a few folks died/ In } \\
\text { the winter of ' } 79\end{array}$ \\
\hline $\begin{array}{l}7 \text { Man You Never Saw } \\
\text { (Robinson, Ambler) }\end{array}$ & $\begin{array}{l}\text { Fantasy about activist } \\
\text { caught up in repression due } \\
\text { to crushed revolution. }\end{array}$ & $\begin{array}{l}\text { "Church police were round this morning/ } \\
\text { And the army's on our track/ Took away } \\
\text { my books and papers/ Only just got out } \\
\text { the back" }\end{array}$ \\
\hline $\begin{array}{l}8 \quad \text { Better Decide } \\
\text { Which Side You're On }\end{array}$ & Call to fight back & $\begin{array}{l}\text { "You better decide which side you're on/ } \\
\text { The chips go down before too long/ If Left } \\
\text { is right then Right is Wrong/ You better } \\
\text { decide which side you're on/ } \\
\text { Too late, trendy thinkers/ Your time is } \\
\text { running out/ Ain't no time to wonder } \\
\text { why/ Ain't no time for doubt/ Joseph, } \\
\text { Reed and Whitehouse/ Are out to get your } \\
\text { guts." }\end{array}$ \\
\hline
\end{tabular}




\begin{tabular}{|c|c|c|}
\hline $\begin{array}{l}9 \text { You Gotta Survive } \\
\text { (Robinson, Ambler) }\end{array}$ & $\begin{array}{l}\text { Dystopian post-apocalyptic } \\
\text { fantasy }\end{array}$ & $\begin{array}{l}\text { Carrion crows on the motorway/ old } \\
\text { woman dying of the plague/ She cried 'put } \\
\text { me out of my misery'/ Charlie had to give } \\
\text { her his blade/ Streets full of slavers on the } \\
\text { rampage/ Wild boys running by the score/ } \\
\text { Weeks without eating/ Can't carry on } \\
\text { anymore }\end{array}$ \\
\hline $\begin{array}{l}10 \text { Power in the } \\
\text { Darkness (Robinson, } \\
\text { Ambler) }\end{array}$ & Call to fight back & \\
\hline \multicolumn{2}{|l|}{ Album TRB Two 1979} & Got to number 18 in the album charts \\
\hline $\begin{array}{l}1 \text { All Right All Night } \\
\text { (Robinson, Kustow, } \\
\text { Dolphin Taylor) }\end{array}$ & $\begin{array}{l}\text { Party song celebrating } \\
\text { multiracial and youth } \\
\text { unity. }\end{array}$ & $\begin{array}{l}\text { "We don't see no place for hatred/ Real } \\
\text { life's too good to waste it/ No-one here's } \\
\text { afraid to face it/ Take it while we can" }\end{array}$ \\
\hline $\begin{array}{ll}2 \quad \text { Why } & \text { Should I } \\
\text { Mind? } & \text { (Robinson, } \\
\text { Kustow) } & \end{array}$ & $\begin{array}{l}\text { Comic fable with many } \\
\text { references to contemporary } \\
\text { politics }\end{array}$ & $\begin{array}{l}\text { "Idi snorting Coca Cola/ Wonders why he's } \\
\text { getting maligned/ Enoch invited him } \\
\text { over/ For a couple of lines/ It's just a sign } \\
\text { of the times" }\end{array}$ \\
\hline 3 Black Angel & $\begin{array}{l}\text { Love song about a white } \\
\text { man falling in love with a } \\
\text { black man }\end{array}$ & $\begin{array}{l}\text { "I've got a friend in Borstal/ I've got a } \\
\text { friend next door/ I've got a friend in my } \\
\text { own double bed/ I've got a real friend in } \\
\text { the law } \\
\text { I've got a friend in Jesus/ But we're just } \\
\text { good friends you see/ Cos I'm in love with } \\
\text { a sweet Black angel/ I know he's coming } \\
\text { after me" }\end{array}$ \\
\hline 4 Let My People Be & $\begin{array}{l}\text { South American radical } \\
\text { peasant narrator reflecting } \\
\text { on the ineffectiveness of } \\
\text { the UN declaration of } \\
\text { human rights. }\end{array}$ & $\begin{array}{l}\text { "Let my people be! Thirty years of empty } \\
\text { declarations!" }\end{array}$ \\
\hline 5 Blue murder & $\begin{array}{l}\text { Protest song about death of } \\
\text { Liddle Towers in police } \\
\text { custody }\end{array}$ & $\begin{array}{l}\text { "So if you figure on staying alive/ button } \\
\text { your lip and just swallow your pride/ and } \\
\text { don't make trouble when your hands are } \\
\text { tied/ Liddley died." }\end{array}$ \\
\hline 6 Bully for you & $\begin{array}{l}\text { Poetic call to avoid violence } \\
\text { in night clubs, pubs etc. }\end{array}$ & $\begin{array}{l}\text { I ain't afraid but I just don't wanna fight } \\
\text { now / This movie's over - so switch that } \\
\text { light out/ Turn of the screw and tomorrow } \\
\text { soon come man/ Wake in the morning, } \\
\text { wonder what've you done man/.. } \\
\text { We don't need no aggravation! } \\
\text { We don't need no aggravation! }\end{array}$ \\
\hline
\end{tabular}




\begin{tabular}{|c|c|c|}
\hline $\begin{array}{l}7 \text { Crossing over the } \\
\text { road }\end{array}$ & $\begin{array}{l}\text { Metaphorical almost } \\
\text { surrealist story, but } \\
\text { suggestion that the } \\
\text { narrator is coming out as } \\
\text { gay. }\end{array}$ & $\begin{array}{l}\text { "Look son, it's not that I care/ But what } \\
\text { about your fiancée/ I said, I'm better off } \\
\text { this way / I'm crossing over the road. }\end{array}$ \\
\hline 8 Sorry Mr Harris & $\begin{array}{l}\text { Parody of bourgeois British } \\
\text { military man overseeing } \\
\text { torture of political activist. }\end{array}$ & $\begin{array}{l}\text { "I'm sorry if the soldiers had to hurt you, } \\
\text { Mr Harris. You haven't really left them } \\
\text { any choice." }\end{array}$ \\
\hline 9 Law and Order & $\begin{array}{l}\text { Comic parody of tough } \\
\text { young Glasgow man turned } \\
\text { racist sheriff in the Wild } \\
\text { West. }\end{array}$ & $\begin{array}{l}\text { "My mommy held tupperware parties/ } \\
\text { Had acne when I was a boy/Headed out } \\
\text { West - expanded my chest/ Now they treat } \\
\text { me like the real McCoy }\end{array}$ \\
\hline 10 Days of Rage & Hyperbolic teenage anger & $\begin{array}{l}\text { "Every year of bitter submission/ Been } \\
\text { plotting my bitter revenge/ The endless } \\
\text { humiliations -/ Gonna tear their eyes to } \\
\text { pieces" }\end{array}$ \\
\hline 11 Hold Out & $\begin{array}{l}\text { Poetic declaration of } \\
\text { tenacity in personal life }\end{array}$ & $\begin{array}{l}\text { "The kiss on your lips tastes of } \\
\text { wormwood/ So swing low, Iscariot, my } \\
\text { friend/ I'm promising you I'm gonna see it } \\
\text { right through/ I'm gonna hold out to the } \\
\text { bitterest end/ Hold out... hold out I'm } \\
\text { gonna hold out to the bitterest end."” }\end{array}$ \\
\hline
\end{tabular}

John Mullen is a professor at the University of Rouen in France. He has published widely both on the history of British popular music and the history of British trade unionism. His full-length study, "The Show Must Go On": Popular Song in Britain during the First World War was published in 2015 by Ashgate/Routledge. He is at present working on an edited volume about popular song around the world in the Great War: Beyond the Question of Morale: Popular Song in the First World War.

\section{BIBLIOGRAPHY}

Bell, Allan, “Language Style as Audience Design”, Language in Society 13 (1984)

Brocken, Michael, The British Folk Revival 1944-2002 (Aldershot, Ashgate, 2003)

Carlet, Yasmine and Seca, Jean-Marie, "Vingt ans de Live Aid : comment le charity rock a-t-il transformé l'engagement politique en musique populaire ?", Les Cahiers de psychologie politique, $\mathrm{N}^{\circ}$ 7 (July 2005).

Chastagner, Claude, De la Culture Rock, Paris, Presses Universitaires de France, 2011. 
Denisoff, R. Serge and Peterson, Richard A. (eds) The Sounds of Social Change (Chicago, Rand McNally, 1972).

Dawson, Ashley, "Love Music, Hate Racism": The Cultural Politics of the Rock Against Racism" in Serge Denisoff and Richard A Peterson (eds), The Sounds of Social Change, (Chicago, Rand McNally \& Co, 1972).

Hennion, Antoine and Vignolle, J.P., Artisans et industriels du disque - essai sur le mode de production de la musique (Paris, CSI-Cordes, 1978).

Herbert, Ruth "Musical and non-musical involvement in everyday life : the case of absorption", Musicae Scientiae I 26, (November 2011).

Marx, Karl, Critique of Hegel's Philosophy of Right (London, Createspace, 2015 [1844]).

Street, John, Music and Politics (Cambridge, Polity, 2012).

\section{NOTES}

1. I'm using "rock" here in its wider sense of the work of the thousands of guitar-bass-drumsvocals bands of the last sixty years.

2. All the songs mentioned in this article were easily available on YouTube at the time of writing.

3. Such as Ian Curtis, Phil Collins, Eric Clapton or Geri Halliwell of Spice Girl fame;

4. Claude Chastagner, De la culture rock (Paris, Presses Universitaires de France, 2011) "Le fondement subversif et transgressif du rock est au cœur de la séduction qu'il exerce”. (p. 18). All translations are mine.

5. "Le rock est subversif par la place qu'il octroie à l'inarticulé, à l'informulé, au son brut et au corps indocile, à tout ce que les formes culturelles dominantes rejettent au nom de la culture". (ibid p. 83)

6. "Le rock est avant tout un art du slogan" (ibid, p. 58)

7. "Rêver à des vies plus intenses, plus dangereuses, plus excitantes que les nôtres". (My emphasis)

8. Introduction to Karl Marx's work A Contribution to the Critique of Hegel's Philosophy of Right

9. John Street, Music and Politics, (Cambridge, Polity, 2012).

10. "Up Against the Wall" Tom Robinson Band, 1978

11. I am developing this idea to speak of the role of the "listener" in popular music, more active than has often been considered.

12. In psychology, much work has been done on how and why certain activities are more "absorbing" than others. See for example Ruth Herbert "Musical and non-musical involvement in everyday life: the case of absorption", Musicae Scientiae I 26, (9 November 2011).

13. Michael Brocken, The British Folk Revival 1944-2002, (Aldershot, Ashgate, 2003)

14. A 1985 album by "Artists against Apartheid" featuring dozens of well-known artistes. This was not focussed on fund raising alone, but on raising awareness of the complicity of Western powers in the maintenance of South African apartheid.

15. The 1984 single by Band Aid involved 41 well-known singers or musicians.

16. For a fuller analysis, see Yasmine Carlet and Jean-Marie Seca, "Vingt ans de Live Aid: comment le charity rock a-t-il transformé l'engagement politique en musique populaire ?", Les cahiers de psychologie politique, $\mathrm{n}^{\circ} 7$ (July 2005).

17. Ashley Dawson, "Love Music, Hate Racism": The Cultural Politics of the Rock Against Racism Campaigns 1976-81" Postmodern Culture 16:1 (September 2005). 
18. Red Wedge, the subject of another article in this volume, may be considered as inspired by a similar conception of the political use of popular music.

19. Evening News (December 1977).

20. In the appendix you will find information about the 26 recorded songs which made up almost their entire output in the three years the group existed.

21. Ten years later, Billy Bragg will follow this option to some extent.

22. $\mathrm{R}$ Serge Denisoff and Richard A Peterson eds The Sounds of Social Change (Chicago, Rand McNally, 1972), p. 17-18.

23. Antoine Hennion and J. P. Vignolle, Artisans et industriels du disque - essai sur le mode de production de la musique (Paris, CSI-Cordes, 1978) p 198.

24. https://www.youtube.com/watch?v=9FUW0anY_Mc

25. https://www.youtube.com/watch?v=yKOUuw8R1aw

26. I have highlighted what I believe to be the main dynamic. There are other things going on: for example, there is a humorous side to the song "The Winter of 79", since it was released in 1978, and could be characterized as wryly hyperbolic.

27. Allan Bell "Language Style as Audience Design", Language in Society 13, (1984)

28. Tom Robinson never seems to pretend to be from the working class, as some have. Indeed in one of his songs he insists "I'm a middle-class kiddie, but I know where I stand".

29. Readers need to remember that homophobia was the majority attitude in the 1970s. The journalist from the New Musical Express wrote "This is one of the most relevant bands I've seen this year, but a lot of people are going to miss them because they can't identify with a group that are glad to be gay". (NME, September 17 1977)

30. Released by Vox in 1968.

31. Sounds, April 16, 1977

32. In the UK today it is known as the logo of the Socialist Workers Party.

33. TRB toured Europe, the United States and Japan.

\section{ABSTRACTS}

The Tom Robinson Band had a distinctive approach to political rock music, in their brief career at the end of the nineteen seventies. Neither underground counter-culture nor stadium charity rock, they tried to encourage grassroots involvement in politics as well as to spread their ideas widely, through the pop charts if necessary. This article takes the band as an example to pose the wider question "What Can Political Rock do?", and develops an approach which puts the concept of the participatory nature of popular music at the centre of the analysis. One of Tom Robinson's songs was named by Time Out as one of "a hundred songs which changed history": our article attempts to show why and how this might be the case.

Cet article vise à poser la question "Que peut faire le rock politique?" à travers une étude de cas. Il s'agit du groupe the Tom Robinson Band, actif entre 1977 et 1979, au moment où le punk rock déferlait sur l'Angleterre et que Rock against Racism mettait en pratique une approche originale aux rapports entre création artistique et militantisme politique. Ni contre-culture marginale, ni Charity Rock produit dans les stades, le répertoire et les méthodes de Tom Robinson valent le détour. Notre approche met le côté participatif de la musique populaire au centre de l'enquête, afin d'explorer les effets éventuels du rock politique sur l'individu. 
INDEX

Mots-clés: rock, Tom Robinson Band, Rock against Racism, culture populaire

Keywords: rock, Tom Robinson Band, Rock against Racism, popular culture

\section{AUTHOR}

\section{JOHN MULLEN}

Université de Rouen, équipe ERIAC 